\title{
Learning Styles of Czech College and University Students in Accounting Education
}

\author{
Kateřina Berková $^{1, *}$, Jana Borůvková ${ }^{1}$, Dagmar Frendlovská ${ }^{1}$, Pavel Krpálek ${ }^{2}$ \\ ${ }^{1}$ College of Polytechnics Jihlava, Czech Republic \\ ${ }^{2}$ College of International and Public Relations Prague, Czech Republic
}

Received April 26, 2020; Revised June 13, 2020; Accepted June 26, 2020

Copyright $\mathrm{O} 2020$ by authors, all rights reserved. Authors agree that this article remains permanently open access under the terms of the Creative Commons Attribution License 4.0 International License

\begin{abstract}
Learning styles represent an important factor influencing the quality of the teaching process. Therefore, the research focuses on examining the preferred learning styles in Accounting at Czech colleges and universities. A total of 132 students of two higher education institutions participated in the study. The questions have been worded in such a way as to determine the style of learning and also whether the students are aware of their sensory preferences. The model was based on the VARK model and on a motivation and intent-oriented learning styles. A Chi-Square Test of Independence was applied for verification purposes. A surface approach to learning prevails in the Accounting subject. The second most common approach is deep learning. In terms of the VARK model, the visual and auditory learning styles are the least frequent. The choice of learning style in Accounting education is influenced by the college/ university Accounting teacher who promotes the surface learning style, the work placement mentor who encourages deep learning, and also by gender, with women preferring surface learning and men the deep learning approach. Other factors (school specialisation, previous experience with the subject gained at secondary school and during work placement, secondary school Accounting teacher, difficulty of the subject at the higher education institution, direct contact with the college/ university teacher, professional interest in the subject) do not significantly influence the style of learning. This research has underlined the necessity of determining students' preferences of learning styles in Accounting education, which will allow for further improvement in teaching.
\end{abstract}

Keywords Learning Styles, VARK Model, Questionnaire Method, Accounting, College and University Students

\section{Introduction}

Considered as important for the effective selection of teaching methods and strategies, the determination of students' learning styles comes to the fore in order to maintain the quality of the teaching process. The learning style is usually based on internal factors (i.e. an individual's personal characteristics) and external factors such as the influence of teachers, mentors, school specialisation, etc. Research [1]. verified that these attributes are a prerequisite for the sustainable educational development of colleges/universities in the context of the practical training of students. The same was also concluded by Allen, Swidler and Keiser [2], who implemented the results into teaching practice. This research proceeds from these findings and research methodologies and further analyzes factors influencing students' learning styles in Accounting at higher education institutions. In terms of economic education the subject of Accounting is important for the future profession of graduates and therefore it is the main field for research. Many studies contributed to the development of Accounting teaching at higher education institutions, when combining the suitability of learning styles used by students and teaching strategies employed by teachers [3-5]. Thanks to these findings, educational activities can be improved [6]. The research [7] actually focused on the reform of educational activities, in relation to learning styles.

The learning style can be defined as an individual learning procedure preferred by a person [8]. The learning style is helpful in processing information and acquiring new knowledge [9]. Kolb defined the learning style as learning based on experience and on practical and laboratory activities [6]. From this, learning styles based on survival, perception, thinking and active action and multisensory learning styles have been defined. Teaching materials are also related to learning styles. 
In 2006, Fleming and Mills developed a simple tool for determining the preferences of sensory modality when processing information, identified as VARK: Visual, Auditory, Reading/writing and Kinaesthetic [10]. The VARK model assumes that each student is able to identify his/her own learning style and can realise his/her sensory preferences [11]. Following a concept of students using various methods of processing information for learning, Kolb's quadrant model was employed for the definition of learning styles based on feeling, watching, thinking and doing.

Furthermore, literature defines various other learning styles. Following the Entwhistle and Newble theory [12], motivation and intent are also important aspects for quality management in the teaching process. The most widely used learning style in this category of styles is the surface style, mostly chosen by students who prefer to expend as little effort on learning as possible [13]. They find it unnecessary to understand the subject matter taught, but they are satisfied to learn it by rote (encoding and storing it in a mechanical memory). This acquisition method is characterised by memorisation aspiring towards the achievement of academic performance, but without a deeper motivation to acquire new knowledge. Motivation is a very important tool for the success [14]. The study examined the impact of the VARK learning style model on academic achievement in the conditions of a university in Turkey over a 10-year period [15]. The research has shown that educational plans developed on the basis of the VARK model have a significant impact on academic achievement and student attitude. Academic achievement did not show any significant difference in the dependence on the learning style model and the type of subject taught. This conclusion contradicts the study [5], which focused on the impact of learning style preferences on learning outcomes of students of the Accounting education study programme at the Faculty of Education in the Islamic University of Riau, where no significant influence has been established. However, neither of these two research papers examined the learning style model in terms of intent and motivation, i.e. the deep and surface learning styles.

The surface learning style is widespread in the Czech Republic [13]. Nevertheless, this style is not a path towards sustainable educational development of higher education institutions; instead, it actually leads to the retention of the student figures regardless of the quality of teaching. Being the opposite to the surface learning style, deep learning is of key importance in learning and teaching processes. Thanks to this style, students realise that the information is interconnected in a certain way and also become aware of the existence of a particular hierarchy in a given set of information. They find personal sense in the teaching content and learning, and they focus on the practical utilisation of knowledge [12].

Another approach applied to analyze the students' preferred learning styles in relation to the quality of the teaching process lies in the dependence on teaching methods and strategies employed by teachers. Such research [4] was conducted for the subject of Accounting at the Federal University of Campina Grande and was based on experiential learning. The object of the study was Kolb learning styles [16]. The prevailing learning style among students was assimilation and among teachers converging. An alignment between learning styles and teaching methods of teachers was achieved, as teachers most often use the expository teaching method along with exercises as a form of teaching. However, incompatibility between students' methods of learning and teachers' methods of teaching exists at a greater extent, which can lead to the disruption of the teaching process and learning by unsatisfactory performance. This research underlined the need to determine the preferred learning styles, thus including the correct teaching strategies in the teaching process. Learning styles in Accounting courses at higher education institutions are a significant scientific issue and have been addressed in many studies.

Dealing with the same topic, the next research showed that $45 \%$ of students used a converging style in Accounting sciences and examined the correlation between the students' style of learning and teachers' style of teaching [17]. The research supports the development of cyclical learning strategies that meet the maximum existing educational needs, especially in a way as to enable teaching of didactics covering all types of students' learning styles. In terms of the VARK learning style model, the study [1] has concluded that students of economic higher education institutions most prefer reading/writing (29.4\%) and the multimodal style (25.7\%). They use the visual style $(8.3 \%)$ the least. The auditory (17.4\%) and kinaesthetic styles reached similar figures, but they do not rank among the most common learning styles $(19.3 \%)$.

There have been many studies that have examined variables affecting learning styles $[1,2,18,19]$. Gender differences in learning styles were found in student research at a higher education institution in marketing and business subjects [18]. Although there was a positive learning experience for both sexes, men and women used different learning styles. This finding had pedagogical implications and the results of the research were put into practice. Gender differences in learning styles were also detected by the research [20]. However, Martín-García [21] concluded the contrary as their research failed to confirm the impact of gender or even the impact of socio-demographic factors such as marital status and level of education. Similarities can be found in other research [1]. The authors have shown that there is no significant association between learning styles and academic performance, gender, employment circumstances, type of the subject taught and student's involvement in work placement or the impact of practical training.

The research was aimed at identifying learning styles preferred by university and college students and was 
inspired by the study [1], which showed that these attributes favourably affected the quality of learning processes on the part of students and also the quality of teaching delivered by teachers in relation to practically oriented subjects. Knowledge of students' learning style preferences creates the prerequisites for achieving the didactic effectiveness of teaching as well as educational and cognitive goals, and it also improves pedagogical communication. This assumption was scientifically proven, for example, also in research carried out in 2012, where its authors focused on the importance of learning styles for the teaching process at universities and colleges [2]. The results of the study were implemented into teaching practice. This article examined preferences of university and college students in the practically oriented subject Accounting and aims and aspired, depending on the results of the research, to design procedures to achieve a higher effect in learning and teaching processes for the subject Accounting. This was helped by knowledge of factors influencing students' learning style preferences. In achieving efficiency of the teaching process, one of the important prerequisites was pedagogical communication mutual communication and understanding between a teacher and a student. Therefore, knowledge of the preferred learning styles, in other words knowledge of the factors that played a significant role in students' learning was essential for the successful work of any teacher.

The research goal is to verify what factors the learning style preferences of Czech college and university students depends on in the practice-oriented subject of Accounting. The dependence is examined using internal variables (personal characteristics of the students), i.e. gender, interest in direct contact with the teacher and professional interest in the subject, and external variables, i.e. Accounting experience from the previous secondary school, practical Accounting experience, influence of the college/university Accounting teacher, influence of the secondary school Accounting teacher, influence of the work placement mentor and the difficulty of the subject. The research is helpful in creating and upgrading teaching strategies and evaluation systems by understanding what learning styles students prefer and what factors are behind this.

The said goal gave rise to the two basic hypotheses that are to be verified:

1. Preferred learning style in Accounting depends on the personal characteristics of the students (gender, interest in direct contact with the teacher and professional interest in the subject).

2. Students' preferred learning style in Accounting depends on the external variables (Accounting experience from the previous secondary school, practical Accounting experience, influence of the college/university Accounting teacher, influence of the secondary school Accounting teacher, influence of the work placement mentor and the difficulty of the subject).

\section{Materials and Methods}

\subsection{Participants}

The research sample was created by purposive sampling as the relevant characteristics of the population significant for this empirical study were determined in advance. The sample had to meet the following criteria: (a) selection of respondents - students of higher education institutions specialising in economic studies; (b) selection of higher education institutions was carried out according to their vision, taking into account the different methods of preparing graduates for practical work; (c) completion of Accounting classes by the students at the college/university, the selection of this subject was supported mainly by the fact that it is a practice-oriented subject, relevant to any economic activity carried out in practice and its position is important at economic higher education institutions; (d) selection of a college/university offering economic study programmes. The research was participated in by two higher education institutions in the Czech Republic with differing visions:

(a) The College of Polytechnics Jihlava, which is a public higher education institution in the Vysočina Region with a practical focus, requiring work placement participation during studies, where practitioners are also involved in the teaching process; (b) University of Economics Prague, Faculty of Finance and Accounting, this faculty does not enable work placement during studies and does not have such a wide portfolio of practice-oriented subjects. The research sample is made up of students from these two higher education institutions particularly for the diversity of the sample, which was inspired by the research [1]. In terms of methodology, the current research is also based on the study [17] focused on students' learning styles in Accounting at a university applying the Kolb theory [22].

A total of 132 students in full-time Bachelor's Study Programmes participated in the research, where 82 students were from the Faculty of Finance and Accounting of the University of Economics and 50 students from the College of Polytechnics Jihlava, reading Finance and Management or Travel and Tourism. These study programmes come under Economic and Management Studies. The research sample met the prerequisite of purposive sampling. The maximum number of students addressed from the Faculty of Finance and Accounting was 90 , i.e. a $91 \%$ response rate. At the College of Polytechnics Jihlava, it was possible to address only 150 students (with regard to the conditions for research involvement) and the response rate reached one third $(33 \%)$. The sample size was further conditioned by students volunteering to be involved in research and due to this it was not possible to obtain a larger sample. At the same time, this condition could be seen as an important factor for increasing the objectivity of the results in view of the possible intentions of respondents to distort the results. For the above reasons, the final total of the 
students involved was 132, and this could be viewed as reliable. The survey was participated in by men $(27 \%)$ and women (73\%), aged 20-22. These were students from the Czech Republic from the Vysočina Region and Prague, the capital of the Czech Republic. The Bachelor's Study level was represented by all (i.e. first to third) grade students at both of the institutions. $62 \%$ of respondents were first grade students, 33\% second grade students and the remaining $5 \%$ of respondents were from the third grade.

\subsection{Instruments}

A questionnaire-based survey method was applied. In order to increase its validity and reliability the research instrument was subjected to pilot verification on a small group of students $(n=5)$ who met the characteristics of the research sample for live data collection. The questionnaire was designed with the object of determining the influence of these factors on students' learning styles preferred in the subject Accounting in tertiary education. It concerned statements of students who answered questions in the questionnaire that were to determine which learning styles the students preferred in this particular subject. The questionnaire contained substantive questions relating to the researched issues and factual questions allowing characterization of the respondents, while however, maintaining their anonymity. The questionnaire was prepared in a way as to determine the influence of these factors on the learning style of students preferred by them when learning Accounting during higher education studies. The research instrument design and the selection of variables were based on the method and research [1], which analyzed learning styles among college/university students of business schools attending two different study programmes and examined the link between learning styles and personal characteristics of respondents.

This study is primarily based on the VARK learning style model, where the auditory and visual styles, which are common in Czech conditions, were selected. Since the VARK model assumes that each student is able to identify his/her own learning style and can realise his/her sensory preferences [11], the questions in the questionnaire were prepared in this way. The VARK model was modified and expanded to include surface and deep learning styles, based on Entwhistle and Newble theory of intent and motivation [12]. The surface and deep learning styles have been made use of in several empirical research studies focused on the Accounting subject at higher education institutions, the most significant for this paper being the research [17]. The questionnaire structure and the wording of the questions are detailed in Table 1, which also shows the variables that have been subject to statistical analysis along with scaling techniques for response selection.

\subsection{Procedure}

The research included students from both higher education institutions, following preliminary discussions with both organisations. The participants were to meet the prerequisites of purposive sampling, i.e. they had to be students of economic study programmes who had completed Accounting classes at the college/university. These were the essential prerequisites for this study. The research was conducted using a questionnaire-based survey. The web format questionnaire was sent in bulk via official emails of both of the institutions in September and October 2019. Students were informed of the research goal and scope. Their involvement was voluntary and anonymous. All data that could be used to identify the students were encrypted or deleted. 
Table 1. Dependent and independent variables contained in the model

\begin{tabular}{|c|c|}
\hline Variable & Category \\
\hline Visual learning style & $\begin{array}{c}\text { I can learn better with the help of images, graphic charts, highlighted } \\
\text { information, algorithms, and diagrams. }\end{array}$ \\
\hline Auditory learning style & I can learn better by retelling the text, listening to it, watching it using video. \\
\hline Deep learning style & $\begin{array}{c}\text { I can learn better through real-life cases/problems that I solve myself; I } \\
\text { search for information and work with it, thus gaining new knowledge. }\end{array}$ \\
\hline Surface learning style & $\begin{array}{c}\text { I can learn better based on what the teacher tells me that is necessary to learn } \\
\text { for the exam, i.e. I am really only interested in academic achievement } \\
\text { guaranteeing my compliance with the study requirements. }\end{array}$ \\
\hline Gender & Male/Female \\
\hline Accounting experience gained at secondary school & Yes/No \\
\hline Accounting experience gained during work placement & Yes/No \\
\hline $\begin{array}{c}\text { College/university Accounting teacher influenced the } \\
\text { student in the learning style }\end{array}$ & Yes/Partly/No \\
\hline $\begin{array}{c}\text { Secondary school Accounting teacher influenced the } \\
\text { student in the learning style }\end{array}$ & Yes/Partly/No \\
\hline $\begin{array}{c}\text { Work placement mentor influenced the student in the } \\
\text { learning style }\end{array}$ & Yes/Partly/No \\
\hline Interest in direct contact with the college/university teacher & Yes/Partly/No \\
\hline Professional interest in the subject & Yes/No \\
\hline Difficulty of the Accounting subject & Yes/Partly/No \\
\hline
\end{tabular}

\subsection{Data Analyzes}

The data were primarily treated as dependent and independent variables. As for the dependent variables, these were the four learning styles used by the students visual, auditory, surface and deep. Independent variables include factors which could influence learning styles such as gender, practical Accounting experience, Accounting experience from the previous secondary school, influence of the work placement mentor, influence of the Accounting teacher at college/university and secondary school, interest in direct contact with the college/university teacher, the professional interest of the student in the subject and difficulty of the subject. The selection of these factors was inspired by the research [1] and the learning style theory based on the motivation and intent of the student [12].

The data analysis worked with two types of variables: (a) those coming only in two categories (Male/Female, $\mathrm{Yes} / \mathrm{No}$ ), and (b) ordinal, coming in three categories (Yes/Partly/No). SPSS statistical software was used for statistical data processing, while a Chi-Square Test of Independence was chosen to determine whether there was an association between the two categorical variables, where at least one was nominal. Using this test, the dependence between students' learning styles (nominal variable) in Accounting and the researched independent factors (dichotomous and ordinal variables) were studied. If the $\mathrm{p}$-value is less than or equal to .05 , a null hypothesis that says the variables are independent is rejected. In this case, the independent variable affects the dependent variable. Where the dependence of the variables was identified by the Chi-Square Test, Cramer's V and Phi coefficients that are suitable for these data were calculated. These coefficients generally range from the values of 0 (no association) to 1 (strong association).

Hypotheses were verified at a significance level of 5\% applying the Chi-Square Test of Independence and the described coefficients. The null hypotheses were worded as follows:

- $\mathrm{H}_{0-1}$ : Preferred learning style in Accounting does not depend on the personal characteristics of the students.

- $\mathrm{H}_{0-2}$ : Students' preferred learning style in Accounting does not depend on the external variables.

\section{Results}

Students of both of the higher education institutions mostly use the surface learning style in Accounting. This style was quoted by $45.5 \%$ of respondents (i.e. 60 students of the research sample). The second most common is the deep learning style (35.6\%, i.e. 47 respondents). The least used learning styles in Accounting at both of the institutions are visual $(12.8 \%$, i.e. 17 students $)$ and auditory (6.1\%, i.e. 8 respondents). The results (Table 2$)$ suggest that in most cases students strive for good academic results regardless of the depth and understanding of the teaching content, which corresponds to the prevalence of surface learning, typical of Czech education. 
Table 2. College/university students' preferred learning style in Accounting

\begin{tabular}{|c|c|c|}
\hline $\begin{array}{c}\text { Preferred learning styles } \\
\text { (Dependent variables) }\end{array}$ & Frequency & Percentage \\
\hline Surface style & 60 & 45.5 \\
\hline Deep style & 47 & 35.6 \\
\hline Visual style & 17 & 12.8 \\
\hline Auditory style & 8 & 6.1 \\
\hline Total & 132 & 100.0 \\
\hline
\end{tabular}

Learning styles differ depending on the characteristics of respondents (Table 3). In studying Accounting the surface learning style is preferred at both of the higher education institutions, regardless of the practical focus of the institution. The differences between the schools are small (College of Polytechnics 46\%, University of Economics Prague 45.1\%). The surface learning style prevails in almost all cases where the students' approach to learning was analyzed. Similarly, students who gained Accounting experience at secondary school and were influenced by the secondary school Accounting teacher, prefer the surface learning style. This may be due to the teachers of the given subject requiring certain standards, applying teaching strategies, as well as due to the age and attitude of students toward the subject. Attitude toward the subject may be related to the students having to comply with school requirements and passing a secondary school leaving examination, since Accounting is a subject included in the leaving examination at secondary economic schools. As to the influence of the secondary school, the surface style of learning is most frequent (47\%), followed by deep learning (36.4\%) in second place. Considering the influence of the secondary school teacher, the surface style of learning is most prevalent in students (over $50 \%$ ).

Table 3. Internal and external variables depending on the learning style (\%)

\begin{tabular}{|c|c|c|c|c|}
\hline \multirow{2}{*}{$\begin{array}{l}\text { Independent variables } \\
\qquad(\mathrm{n}=132)\end{array}$} & \multicolumn{4}{|c|}{ Preferred learning styles } \\
\hline & D & $\mathrm{S}$ & $\mathrm{V}$ & A \\
\hline $\begin{array}{c}\text { Gender } \\
\text { Male (36) } \\
\text { Female (96) } \\
\end{array}$ & $\begin{array}{l}47.2 \\
31.3 \\
\end{array}$ & $\begin{array}{l}25.0 \\
53.1\end{array}$ & $\begin{array}{l}13.9 \\
12.5 \\
\end{array}$ & $\begin{array}{c}13.9 \\
3.1\end{array}$ \\
\hline $\begin{array}{c}\text { Specialisation of the higher education institution } \\
\text { College of Polytechnics } \\
\text { Jihlava (50) } \\
\text { University of Economics } \\
\text { Prague (82) } \\
\end{array}$ & 32.9 & 45.1 & 8.0 & $\begin{array}{l}6.0 \\
6.1\end{array}$ \\
\hline $\begin{array}{c}\text { Practical Accounting experience } \\
\text { Yes (23) } \\
\text { No }(109) \\
\end{array}$ & $\begin{array}{l}43.5 \\
33.9 \\
\end{array}$ & $\begin{array}{r}43.5 \\
45.9 \\
\end{array}$ & $\begin{array}{c}8.7 \\
13.8 \\
\end{array}$ & $\begin{array}{r}4.3 \\
6.4 \\
\end{array}$ \\
\hline $\begin{array}{c}\text { Accounting experience from secondary school } \\
\text { Yes }(66) \\
\text { No }(66)\end{array}$ & $\begin{array}{l}36.4 \\
34.8\end{array}$ & $\begin{array}{l}47.0 \\
44.0\end{array}$ & $\begin{array}{l}12.1 \\
13.6\end{array}$ & $\begin{array}{l}4.5 \\
7.6\end{array}$ \\
\hline $\begin{array}{c}\text { Influence of the college/university teacher } \\
\text { Yes (91) } \\
\text { Partly (6) } \\
\text { No (35) } \\
\end{array}$ & $\begin{array}{l}36.3 \\
66.7 \\
28.6\end{array}$ & $\begin{array}{l}41.8 \\
0.0 \\
62.9\end{array}$ & $\begin{array}{c}16.5 \\
33.3 \\
0.0\end{array}$ & $\begin{array}{c}5.4 \\
0 \\
8.5\end{array}$ \\
\hline $\begin{array}{c}\text { Influence of the secondary school teacher } \\
\text { Yes (50) } \\
\text { Partly (25) } \\
\text { No (57) }\end{array}$ & $\begin{array}{l}36.0 \\
33.0 \\
36.8\end{array}$ & $\begin{array}{l}50.0 \\
51.0 \\
40.4\end{array}$ & $\begin{array}{l}12.0 \\
12.0 \\
12.3\end{array}$ & $\begin{array}{r}2.0 \\
4.0 \\
10.5\end{array}$ \\
\hline $\begin{array}{c}\text { Influence of the work placement mentor } \\
\text { Yes (25) } \\
\text { Partly (48) } \\
\text { No (59) }\end{array}$ & $\begin{array}{l}64.0 \\
25.0 \\
32.2 \\
\end{array}$ & $\begin{array}{l}24.0 \\
54.2 \\
45.8 \\
\end{array}$ & $\begin{array}{l}12.0 \\
15.6 \\
11.9 \\
\end{array}$ & $\begin{array}{c}0 \\
5.2 \\
10.1 \\
\end{array}$ \\
\hline $\begin{array}{c}\text { Interest in direct contact with the } \\
\text { college/university teacher } \\
\text { Yes (92) } \\
\text { Partly (28) } \\
\text { No (12) }\end{array}$ & $\begin{array}{l}35.9 \\
35.7 \\
33.3 \\
\end{array}$ & $\begin{array}{l}47.8 \\
39.3 \\
41.7\end{array}$ & $\begin{array}{c}9.8 \\
25.0 \\
8.3 \\
\end{array}$ & $\begin{array}{c}6.5 \\
0 \\
16.7 \\
\end{array}$ \\
\hline $\begin{array}{l}\text { Professional interest in the subject } \\
\text { Yes (74) } \\
\text { No }(58)\end{array}$ & $\begin{array}{l}37.8 \\
32.8\end{array}$ & $\begin{array}{l}41.9 \\
50.0\end{array}$ & $\begin{array}{l}14.9 \\
10.3\end{array}$ & $\begin{array}{l}5.4 \\
6.9\end{array}$ \\
\hline $\begin{array}{l}\text { Difficulty of the subject at the higher education } \\
\text { institution } \\
\text { Yes (53) } \\
\text { Partly (18) } \\
\text { No (61) }\end{array}$ & $\begin{array}{l}39.6 \\
27.8 \\
34.4\end{array}$ & $\begin{array}{l}47.2 \\
38.9 \\
45.9\end{array}$ & $\begin{array}{c}7.5 \\
22.2 \\
14.7\end{array}$ & $\begin{array}{c}5.7 \\
11.1 \\
5.0\end{array}$ \\
\hline
\end{tabular}


In terms of the influence of the college/university Accounting teacher under the conditions of the higher education institution, there have been smaller differences between the surface and deep learning styles than under the conditions of secondary education. However, the surface style of learning still prevails (41.8\%). Taking into consideration the difficulty of Accounting at the higher education institution, professional interest of the student in the given subject at college/university and the interest in direct contact with the teacher, the surface style of learning is also dominant. The deep learning style is used by students who were influenced by the mentor during the work placement and differences are also evident in terms of gender. This style is used more by men than women who, unlike men, learn Accounting in a more superficial manner, which may be due to their different attitude to the given subject.

Since the auditory and visual styles of learning were represented at a negligible level, the analysis focused on internal and external factors influencing deep and surface learning styles. The results are presented in Table 4.

The students' preferred learning style in the subject Accounting depends on the external factors related to the teacher's personality, whether it is a college/university teacher and a work placement mentor. At the same time, the learning style in Accounting is significantly conditioned by gender. The learning style is influenced by an internal factor - gender. As to other variables examined (experience with a secondary school subject, experience gained from work placement, influence of the secondary school teacher, interest of the student in the subject, interest of the student in direct contact with the college/university teacher, difficulty of the subject), no significant influence on the students' learning style in Accounting has been identified.

The surface approach and deep problem-based learning styles depended on the internal and external factors. They represented gender, teacher's personality, whether it is a college/university teacher or a work placement mentor (Table 4). Table 3 also clearly shows that these factors were mainly related to the deep problem-based learning style, which was characterized by a deeper penetration into the problem and its understanding. However, the Cramer V and Phi coefficients range from .20 to .36 in this research, indicating a weaker dependence of the learning style on these factors.

At the significance level of $5 \%$, the researchers reject $\mathrm{H}_{0-1}$ hypothesis in the case of gender. At the significance level of $5 \%$, the researchers reject $\mathrm{H}_{0-2}$ hypothesis in the case of the teacher's personality, whether it is a college/university teacher or a work placement mentor.

Table 4. Dependence between the preferred learning styles and internal and external variables

\begin{tabular}{|c|c|c|c|c|c|}
\hline \multirow{2}{*}{ Independent variable } & Chi-Square & \multicolumn{2}{|c|}{ Phi } & \multicolumn{2}{c|}{ Cramer's V } \\
\cline { 2 - 6 } & $\mathbf{p}$ & value & P & value & p \\
\hline Gender & .011 & .245 & .011 & .245 & .011 \\
\hline Accounting experience gained at secondary school & .951 & .006 & .951 & .006 & .951 \\
\hline Accounting experience gained during work placement & .544 & -.059 & .544 & .059 & .544 \\
\hline Influence of the college/university teacher & .025 & .263 & .025 & .263 & .025 \\
\hline Influence of the secondary school teacher & .795 & .065 & .795 & .065 & .795 \\
\hline Influence of the work placement mentor & .007 & .305 & .007 & .305 & .007 \\
\hline Direct contact with the college/university teacher & .926 & .038 & .926 & .038 & .926 \\
\hline Professional interest in the subject & .414 & -.079 & .414 & -.079 & .414 \\
\hline Difficulty of the subject at the higher education \\
institution
\end{tabular}




\section{Discussion}

This research brought new findings in the field focusing on the influence of the internal and external factors influencing the students' preferred learning style in the subject Accounting. The research concentrated on the VARK model and learning styles based on motivation and intent. Due to the finding that students preferred the surface approach and deep problem-based learning styles when studying Accounting, the significance of factors influencing students' preferences was examined in relation to these two learning styles. The research showed that the deep problem-based and surface approach learning styles, which could be considered dominant from the point of view of students' preferences in Accounting, was influenced by gender, the teacher's personality, whether it is a college/university teacher or a work placement mentor. This knowledge is essential for the research, as the facts that were compared with other similar studies give an indication, in particular, of socio-demographic variables, but do not directly provide information about the factors related to the teaching process. Men and students influenced by the teacher's personality, whether it is a college/university teacher or a work placement mentor prefer the deep problem-based learning style.

Two more learning styles were chosen for the model, where the researchers expected their possible use in Accounting education. It was a visual and auditory learning style according to the VARK model $[10,11]$. The research has not proved the use of learning styles according to this model among Czech students.

In the international context, the findings are different. These learning styles prevail according to the VARK model. A contradiction can be found with a research study which has shown that students of economic colleges and universities use learning styles according to the VARK model [1]. Most represented are reading / writing styles and multimodal style. The least represented is visual style of learning. Concerning the visual style, the findings correspond to this research. According to the VARK model learning styles are important for their influence on academic achievement as well as on students' attitudes to subjects [15], provided the learning plans are adapted to this model, i.e. students are guided and instructed in learning styles. The prerequisite is that these styles are implemented directly into the teaching methodologies of the degree programmes. Otherwise, the influence of the learning style model on academic achievement might not be functional. This influence has not been proven by research [5] in Accounting education at university. This may be due to the greater freedom in forming learning styles, i.e. the incompatibility between the way students learn and the way teachers teach. Such a phenomenon leads to disruption of the teaching and learning process by unsatisfactory performance [4].

The main reasons why the VARK model is not used in the Czech Republic include the way of teaching and the selection of teaching strategies and methods. For the sample, the surface style of learning prevails, which may be conditioned by the requirements imposed on students in the subject. Teaching methods and strategies applied by teachers are a significant factor in the student's learning style in Accounting [3-5]. The mentioned studies have contributed to the development of Accounting teaching at colleges and universities, combining the appropriateness of the learning style used by students and teaching methods. Therefore, they can serve as an inspiration for applying the results to practice. On the grounds of these findings, pedagogical activity has gradually been improving, as stated by other research [6,7].

In order to base the reasons why the surface learning style is more widespread in Czech colleges and universities (specifically in Accounting), the factors significantly influencing the style of learning in this subject were analyzed more into the detail. Factors were analyzed only for the surface and deep learning styles that were most frequently represented. They significantly influence: the learning style in Accounting, gender, teacher of Accounting in higher education and work placement mentor. These results are consistent with research [20], which showed gender differences in learning styles. This research has shown that men benefit from a deep learning style unlike women who prefer a surface learning style. The effect of gender was found at the significance level of $5 \%$ by research as well [18]. This research dealt with marketing and business. However, the surface and deep learning styles were not researched, but the research was based on the VARK model.

Other factors, among which the following ones have been included (experience with Accounting at secondary school, work experience, influence of Accounting teacher at secondary school, difficulty of the subject, direct contact with Accounting teacher at colleges and universities, professional interest in the subject) are not significant within the sample. These results are consistent with the research (Espinoza-Poves et al., 2019) which has shown that there is no significant link between learning styles and the impact of teaching practice, student engagement in work placement, students' age, employment situation and subject type.

A college or university Accounting teacher supports a surface learning style, which is mainly due to the graduation requirements. It can be stated that students do not have to be so motivated to study Accounting and try to succeed only because of academic achievement [23]. The mentioned research found that students of economic programmes at the College of Polytechnics Jihlava were indifferent to deeper knowledge in Accounting and only good academic results were the motivation for them.

Work placement mentor develops deep learning style in Accounting. Work placement is currently important for tertiary education. In the study programmes of colleges 
and universities, several attributes helping to achieve practice-oriented educational goals are increasingly seen. It is mainly about completing the work placement during the studies and involving of experts working in the field in the teaching process, in which case this changes the form or method of teaching, which is more based on experiential learning. This type of education is more beneficial for the students themselves [24] and contributes to strengthening students' abilities to improve their academic performance $[1,25]$. The research [26], which confirms that academia is primarily focused on academic research but lacks significant practical experience or certification of higher education teachers, can be used to illustrate why this is the case. After graduation, students may lack the practical skills required by the labour market. It is therefore necessary to direct the teaching more towards practical training using mentors working in the field and methods based on case study solutions, as well as making the teaching more interesting with various excursions in the field, internships or practical training. This teaching procedure can contribute to the increase of the didactic efficiency of education in a practically oriented subject such as Accounting.

Some research limitations need to be highlighted. At first it should be noted that the sample of 132 students is not large enough to generalize the results. The sample could have influenced the results, which are also inconsistent with similar studies. The sample was compiled by deliberate sampling, which corresponds to the main research intent. However, the proportion of students from both tertiary institutions - university and college is not balanced in terms of numbers, which is another factor affecting the end results. The results can only be applied to a specific subject, but the research methodology used has a broader impact on the future similar research. The advantage of the methodology used lies primarily in the possibility of its simply application to practically oriented subjects other than Marketing. Subsequently, it enables exploring learning style preferences of students across the study portfolio and determining whether students use only one learning style or vary them according to the studied subject.

\section{Conclusions}

Further research will extend this topic, namely on the knowledge of which factors influence learning styles according to the VARK model, which is widespread in the international environment and whether it can be applied not only to the subject of Accounting, but to other economic subjects at colleges and universities. According to research results, the teaching of Accounting should be more practice-oriented through teaching by experts working in the field. Teaching methods should be compatible with learners' learning styles, which must be directed to a deep learning style as it is more beneficial to understand the importance of the subject. This could be guaranteed by having more experts working in the field in the teaching process.

It will also be useful to explore the relations between learning styles and motivation, learning habits, learning environment, subject types, academic performance, etc., which may be critical to the learning process. They are being studied but they bring contradictions in the results of many studies. Future articles will be focused on extending the model by other variables in terms of socio-demographic factors, such as marital status and level of education. By examining these relations, it will be possible to achieve even better educational objectives and didactic effectiveness in education.

\section{Acknowledgments}

This research was supported by the College of Polytechnics, Jihlava, Czech Republic, under Grant No. $1170 / 4 / 194$ "Interactive teaching form as a paradigm of the educational process".

\section{REFERENCES}

[1] J. L. Espinoza-Poves, W. A. Miranda-Vilchez, R. Chafloque-Cespedes. The vark learning styles among university students of business schools, Propositos y representaciones, Vol.7, No.2, 400-415, 2019.

[2] S. Allen, M. Swidler, J. Keiser. Aligning pedagogy of American business language with marketing students' preferred learning styles, Procedia - Social and Behavioral Sciences, Vol.70, 1254-1264, 2013.

[3] S. H. Barbosa Granados, M. L. Amariles Jaramillo. Learning styles and the use of ICT in university students within a competency-based training model, Journal of new approaches in educational research, Vol.8, No.1, 1-6, 2019.

[4] M. P. de Andrade Simões, L. S. Albuquerque de Mělo, F. F. Batista, G. M. Pereira Cirne. Relational analysis between learning styles and teaching methods in the one Accounting course, Revista Evidenciacao Contabil \& Financas, Vol.6, No.2, 75-95, 2018.

[5] P. A. Wijaya, N. Nurhuda. Learning style ces and self-regulated learning and their effects on learning outcomes students of the Accounting education study program Faculty of education - The Islamic university of Riau, 3rd International Conference on Tourism, Economics, Accounting, Management, and Social Science, AEBMR-Advances in Economics Business and Management Research, 258-261, 2018.

[6] A. Y. Kolb, D. A. Kolb. The Kolb learning style inventory version 3.12005 technical specifications, Hay Resources Direct, Boston, 2005. 
[7] B. Yang, W. Chen. Impact of data analysis on the business administration education reform in teaching style, Educational Sciences-Theory \& Practice, Vol.18, No.5, 2124-2133, 2018

[8] L. Fenyvaisová. Vyučovacie metódy a interakčný štýl učitel'a (Teaching methods and teacher interaction style), PdF UKF, Nitra, 2006.

[9] D. A. Kolb. The learning styles inventory, McBeer, Boston, Mass, 1985.

[10] J. García Nájera. The VARK model: instrument designed to identify teaching styles - learning, Investigación Educativa Duranguense, Vol. 6, 86-90, 2007.

[11] A. Sarmiento, C. Mayté, T. Tuyub. Identification of the predominant learning styles of students in the upper middle level in an ICT-mediated environment by developing questionnaires, Revista Electrónica del Desarrollo Humano para la Innovación Social, Vol.4, No.8, 15 p., 2017.

[12] N. Entwistle. Styles of learning and teaching, John Wiley \& Sons, New York, 1981.

[13] J. Škoda, P. Doulík. Psychodidaktika: Metody efektivního a smysluplného učení a vyučování (Psychodidactics: Methods of effective and meaningful learning and teaching), Grada, Prague, 2011.

[14] I. Kuchařová, K. Berková, D. Pfeiferová, P. Krpálek. The Influence of teacher competencies on student motivation to study Accounting at secondary vocational schools in the Czech Republic, Universal Journal of Educational Research Vol.7, No.12, 2844 - 2850, 2019.

[15] S. Kanadli. A meta-analysis on the effect of instructional designs based on the learning styles models on academic achievement, attitude and retention, Educational Sciences-Theory \& Practice, Vol.16, No.6, 2057-2086, 2016.

[16] D. A. Kolb. Learning style inventory: version 3, Hay/McBer, Boston, 1999.

[17] A. M. Meurer, D. R. Pedersini, R. A. Antonelli, S. B. Voese. Learning styles and academic performance at the university, Reice-revista Iberoamericana Sobre Calidad Eficacia y
Cambio en Education, Vol.16, No.4, 23-43, 2018.

[18] L. L. Garber, E. M. Hyatt, U. O. Boya. Gender differences in learning preferences among participants of serious business games, International Journal of Management Education, Vol.15, No.2, 11-29, 2017.

[19] G. L. Karns. Learning style differences in the perceived effectiveness of learning activities, Journal of Marketing Education, Vol.28, 56-63, 2006.

[20] F. Cano. Gender differences in learning strategies and styles, Psicothema, Vol.12, No.3, 360-367, 2000.

[21] A. Martín-García. Learning styles in older adults. A study about experiential learning theory, Revista Española de Geriatría y Gerontología, Vol.38, No.5, 258-265, 2003.

[22] D. A. Kolb. Experimental learning: Experience as the source of learning and development, Prentice-Hall, Upper Saddle River, NJ, 1984.

[23] K. Berková, J. Borůvková, L. Lízalová. Motivation of students of economic and technical fields as a tool of competitiveness of Universities and Colleges: Empirical study, Journal on Efficiency and Responsibility in Education and Science, Vol.11, No.4, 72-77, 2018.

[24] A. Pratama. Bridging the gap between academicians and practitioners on accountant competencies: An Analysis of international education standards (IES) implementation in Indonesia's Accounting education, 2nd Global Conference on Business and Social Sciences (GCBSS) on Multidisciplinary Perspectives on Management and Society, Global Academy of Training \& Research, 19-26, 2015.

[25] F. Shirazi, S. Heidari. The relationship between critical thinking skills and learning styles and academic achievement of nursing students, Journal of Nursing Research, Vol.27, No.4, 1-7, 2019.

[26] K. J. Smith, D. J. Emerson. An analysis of professional competence indicator possession among U.S. Accounting faculty, Issues in Accounting Education, Vol.32, No.2, 17-38, 2017. 